\title{
Validitas Instrumen Penalaran Ilmiah Pada Materi Sistem Pertahanan Tubuh Kelas XI
}

\author{
Devitia Hamsyah, Lesy Luzyawati*, Eva Yuliana \\ Program Studi Pendidikan Biologi, Fakultas Keguruan dan Ilmu Pendidikan, Universitas Wiralodra \\ email: lesy.luzyawati@unwir.ac.id
}
APA Citation: Hamsyah, D., Luzyawati, L., \& Yuliana E. (2021). Validitas Instrumen Penalaran Ilmiah Pada Materi Sistem Pertahanan Tubuh Kelas XI. Quagga: Jurnal Pendidikan dan Biologi, 13(1), 26-33. doi: 10.25134/quagga.v13i1.3474.

Received: 08-09-2020

Accepted: $30-10-2020$

Published:01-01-2021

\begin{abstract}
Abstrak: Pada abad ke 21 kemampuan bernalar merupakan kemampuan yang harus dimiliki siswa dalam memecahkan permasalahan dan proses pembelajaran harus dapat menilai penalaran ilmiah siswa. Akan tetapi hasil lapangan menemukan bahwa pada beberapa guru biologi belum pernah melakukan penilaian penalaran ilmiah pada siswa, sehingga penelitian ini akan mengembangkan instrumen penalaran ilmiah pada materi sistem pertahanan tubuh. Tujuan penelitian ini adalah untuk mengetahui validitas produk instrumen penalaran ilmiah. Jenis penelitian ini adalah penelitian pengembangan $(R \& D)$ dengan pendekatan model $4 \mathrm{D}($ Define, Design, Develop and Dessiminate). Populasi sampel yang diambil dalam penelitian ini adalah 5 validator yang terdiri dari 3 Dosen sebagai ahli penalaran ilmiah, ahli materi dan 2 Guru praktisi. Teknik pengambilan sampel menggunakan purposive sample. Teknik pengumpulan data menggunakan lembar validasi dan lembar wawancara. Hasil validasi yang dilakukan dua kali berada pada kategori validitas sangat tinggi, hal ini menunjukan bahwa produk instrumen penalaran ilmiah pada materi sistem pertahanan tubuh kelas XI yang peneliti kembangkan layak untuk digunakan.
\end{abstract}

Kata Kunci: Instrumen penilaian; penalaran ilmiah; sistem pertahanan tubuh

\begin{abstract}
In the 21st century the ability to reason is an ability that students must have in solving problems. In this case the learning process must be able to assess students' scientific reasoning. However, the field results found that some biology teachers have never conducted scientific reasoning assessments on students, so this research will develop scientific reasoning instruments on the body's defense system material. The purpose of this study was to determine the product validity of scientific reasoning instruments. Type of research is development research $(R \& D)$ with a 4 D model approach (Define, Design, Develop and Dessiminate). The sample population taken in this study were 5 validators consisting of 3 lecturers as scientific reasoning experts, material experts and 2 teacher practitioners. The sampling technique used purposive sample. Data collection techniques using validation sheets and interview sheets. The results of the validation that were carried out twice were in the very high validity category, This shows that the product of scientific reasoning instruments in the class XI body defense system material that the researcher developed is suitable for use.
\end{abstract}

Keywords: Assessment instrument; scientific reasoning; body defense system

\section{PENDAHULUAN}

Pembelajaran tidak terlepas dari suatu penilaian dalam melihat hasil belajar siswa. Penilaian dalam pembelajaran bertujuan untuk mengukur kemampuan dan keterampilan siswa. Penilaian dalam Kurikulum 2013 menuntun siswa dapat memecahkan permasalahan sebagai orientasi utama dalam pembelajaran (Lamapaha, 2017). Pemecahan masalah merupakan kemampuan HOTS yang proses berpikir peserta didik dalam level kognitif yang lebih tinggi (Dinni, 2018). Proses berpikir kritis digambarkan dalam menggabungkan konsepkonsep melalui analisis masalah, membuat keputusan, berusaha memahami sesuatu, dan menemukan jawaban untuk masalah (Rasyid et al., 2020). Salah satu keterampilan abad 21 yang perlu di latihkan kepada siswa yaitu keterampilan penalaran ilmiah (Scientific reasoning) (Saad et al., 2017).

Penalaran ilmiah adalah keterampilan berpikir tingkat tinggi terkait dengan kemampuan untuk mengidentifikasi, menganalisis dan memecahkan masalah secara kreatif dan berpikir secara logis sehingga menghasilkan pertimbangan dan keputusan yang tepat (Novia \& Riandi, 2017). Sedangkan menurut Purwati et al., (2016) Penalaran ilmiah merupakan kemampuan dalam menyimpulkan berdasarkan bukti-bukti yang ada. Proses 
bernalar mencakup kemampuan berpikir yang terlibat dalam investigasi, eksperimen, evaluasi bukti, inferensi, dan argumentasi (Zimmerman, 2005). Penalaran ilmiah merupakan salah satu faktor yang mempengaruhi prestasi siswa (Coletta et al., 2008). Kemampuan bernalar yang sangat tinggi berimbas pada kemampuan siswa dalam menyelesaikan suatu masalah (Utama et al., 2018). Pendapat diatas berhubungan dengan pendapat Nur'Aini et al., (2018) yang menjelaskan bahwa penalaran ilmiah merupakan keterampilan tingkat tinggi atau higher order thinking yang harus dimiliki oleh siswa SMA/MA sederajat di abad 21 yang memberikan kontribusi dalam keterampilan kognitif siswa. Berdasarkan penjelasan beberapa ahli tentang penalaran ilmiah dapat disimpulkan bahwa penalaran ilmiah adalah salah satu keterampilan bernalar yang membuat siswa mampu memecahkan suatu masalah dalam kehidupan yang menerapkan konsep dan teoriteori dalam kegiatan penyelidikan ilmiahnya yang harus dimiliki siswa abad 21. Akan tetapi penelitian Aripin (2018) mengungkapkan bahwa rendahnya kemampuan peserta didik dalam berpikir, khususnya berpikir kritis tidak terlepas dari evaluasi atau penilaian yang hanya mengukur tingkat kemampuan dasar saja, dan penelitian Khoirina et al., (2018) yang mengungkapkan bahwa kemampuan penalaran ilmiah siswa SMA pada tingkat penalaran konkret, transisi, dan penalaran formal masih berada pada kategori sedang.

Berdasarkan penjelasan diatas peneliti melakukan wawancara kepada guru dan memperoleh informasi bahwa pada beberapa guru dalam penilaian kemampuan siswa sudah menggunakan soal-soal pemecahan masalah. Namun, soal yang diterapkan belum menyentuh pada kemampuan bernalar ilmiah, sehingga perlu adanya pengembangan soal instrumen tes penalaran ilmiah. Dalam hal ini peneliti mengembangankan instrumen penalaran ilmiah menggunakan tes LCTSR (Lawson Classroom Test Scientific Reasoning) dengan indikator konservasi massa atau volume, penalaran probabilitas, penalaran proporsional, penalaran korelasional, pengendalian variabel, dan penalaran hipotesis-deduktif (Lawson, 2004). Dalam pembuatan butir soal harus memperhatikan aspek yang ingin dinilai dalam soal untuk mencapai tujuan dari pembelajaran (Kartowagiran, 2012). Pemilihan materi yang dikembangkan adalah sistem pertahanan tubuh. Materi tersebut merupakan materi abstrak yang membutuhkan penalaran ilmiah untuk memahami setiap konsep-konsepnya. Pemilihan materi sejalan dengan pendapat Pribadi et al., (2018) yang menyebutkan bahwa materi sistem pertahanan tubuh merupakan materi dengan konsep yang kompleks karena dalam memahami proses pada sistem organnya tidak dapat diamati secara langsung, sehingga salah memahami konsep akan berpeluang mengakibatkan miskonsepsi Berdasarkan latar belakang tersebut, maka peneliti mengembangkan instrumen penalaran ilmiah yang bertujuan untuk menilai kemampuan bernalar siswa dalam pemecahan masalah.

\section{METODOLOGI PENELITIAN}

Jenis penelitian ini adalah penelitian pengembangan (development research) dengan menggunakan pendekatan 4D yakni Define, Design, Develop, Disseminate (Rochmad, 2012). Penelitian yang dilakukan dengan pembatasan tahap Develop, sedangkan tahap Disseminate tidak dilakukan karena himbauan WHO mengumumkan COVID-19 sebagai pandemi. Teknik pengambilan sampel menggunakan purposive sampling. Sampel menggunakan lima orang validator yaitu tiga orang Dosen yang merupakan ahli penalaran ilmiah, ahli materi dan dua orang guru Biologi sebagai praktisi. Teknik pengumpulan data menggunakan lembar validasi dan lembar wawancara. Penelitian dilaksanakan pada bulan Juli - Agustus 2020. Analisis data terdiri dari dua teknik yaitu kuantitatif dan kualitatif. Data kuantitatif berupa saran-saran dari validator kemudian dianalisis untuk memperbaiki produk, sedangkan data kualitatif berupa skor penilaian yang diberikan oleh validator kemudian dianalisis menggunakan Statistik V'Aiken dengan rumus:

keterangan:

$$
V=\frac{\sum S}{[n(c-1)]}
$$

$\mathrm{V}=$ validitas

$\mathrm{s}=\mathrm{r}-\mathrm{lo}$

lo = angka penilaian validitas yang terendah

$\mathrm{c}=$ angka penilaian validitas yang tertinggi

$\mathrm{r}=$ angka yang diberikan oleh seorang penilai

$\mathrm{n}=$ banyaknya validator 
Tabel 1. Kriteria Validitas

\begin{tabular}{cc}
\hline Hasil Validitas & Kriteria Validitas \\
\hline $0,80<\mathrm{V}<1,00$ & Sangat Tinggi \\
$0,60<\mathrm{V}<0,80$ & Tinggi \\
$0,40<\mathrm{V}<0,60$ & Cukup \\
$0,20<\mathrm{V}<0,40$ & Rendah \\
$0,00<\mathrm{V}<0,20$ & Sangat rendah \\
\hline & Sumber: (Fadillah, 2017)
\end{tabular}

\section{HASIL DAN PEMBAHASAN \\ Hasil penelitian \\ Tahap Define}

Hasil wawancara tersebut mengungkapkan bahwa guru belum pernah melakukan penilaian penalaran ilmiah pada siswa, sehingga belum adanya instrumen penalaran ilmiah. Hasil wawancara tersebut dijadikan peneliti sebagai analisis kebutuhan awal dalam mengembangkan instrumen penalaran ilmiah.

\section{Tahap Design}

Hasil analisis Kompetensi Dasar memperoleh enam indikator pembelajaran pada materi sistem pertahanan tubuh yang kemudian, dilakukan desain awal prototype instrumen penalaran ilmiah yang sesuai dengan indikator pembelajaran dan indikator penalaran ilmiah dengan hasil:

1. Indikator penalaran konservasi dengan indikator pembelajaran dalam mengetahui fungsi dan pentingnya sistem pertahanan tubuh, dan menemukan penyebab terjadinya suatu penyakit. Penerapan kedua indikator tertuang dalam soal nomor 1 dan 11 .

2. Indikator penalaran proposional dengan indicator pembelajaran dalam meyelidiki reaksi sistem pertahanan tubuh dalam melawan bakteri atau virus. Penerapan kedua indicator tertuang dalam soal nomor 2 .

3. Indikator pengontrol variabel dengan indikator pembelajaran dalam menjelaskan fungsi dan pentingnya sistem pertahanan tubuh, menemukan penyebab terjadinya suatu penyakit, dan mengemukakan peran pertahanan nonspesifik atau spesifik. Penerapan kedua indikator tertuang dalam soal nomor 3, 4 dan 12 .

4. Indikator penalaran probabilistic dengan indikator pembelajaran dalam memaparkan interaksi antibodi dan antigen, dan menyelidiki reaksi sistem pertahanan tubuh dalam melawan bakteri atau virus. Penerapan kedua indikator tertuang dalam soal nomor 5, 6 dan 13.
5. Indikator penalaran korelasi dengan indikator pembelajaran dalam menemukan penyebab terjadinya suatu penyakit, dan meyelidiki reaksi sistem pertahanan tubuh dalam melawan bakteri atau virus. Penerapan kedua indikator tertuang dalam soal nomor 7 , 8 dan 14.

6. Indikator penalaran hipotesis deduktif dengan indikator pembelajaran dalam mengemukakan peran pertahanan nonspesifik atau spesifik, menjelaskan fungsi dan pentingnya sistem pertahanan tubuh, dan membandingkan mekanisme kerja pertahanan nonspesifik dan spesifik. Penerapan kedua indikator tertuang dalam soal nomor 9, 10 dan 15 .

\section{Tahap Develop}

Tahap Develop dilakukan dua kali validasi produk dengan hasil yang terdapat pada Tabel 2 sebagai berikut:

Tabel 2. Hasil Validasi

\begin{tabular}{|c|c|c|c|c|}
\hline $\begin{array}{c}\text { No } \\
\text { Soal }\end{array}$ & $\begin{array}{l}\text { Validasi } \\
\text { Pertama }\end{array}$ & Keterangan & $\begin{array}{c}\text { Validasi } \\
\text { Kedua }\end{array}$ & Keterangan \\
\hline 1 & 0.56 & Cukup & 1 & $\begin{array}{c}\text { Sangat } \\
\text { tinggi }\end{array}$ \\
\hline 2 & 0.64 & Tinggi & 0.94 & $\begin{array}{c}\text { Sangat } \\
\text { tinggi }\end{array}$ \\
\hline 3 & 0.63 & Tinggi & 0.97 & $\begin{array}{c}\text { Sangat } \\
\text { tinggi }\end{array}$ \\
\hline 4 & 0.83 & $\begin{array}{l}\text { Sangat } \\
\text { tinggi }\end{array}$ & 0.9 & $\begin{array}{c}\text { Sangat } \\
\text { tinggi }\end{array}$ \\
\hline 5 & 0.6 & Cukup & 0.84 & $\begin{array}{l}\text { Sangat } \\
\text { tinggi }\end{array}$ \\
\hline 6 & 0.6 & Cukup & 0.87 & $\begin{array}{l}\text { Sangat } \\
\text { tinggi }\end{array}$ \\
\hline 7 & 0.57 & Cukup & 0.97 & $\begin{array}{l}\text { Sangat } \\
\text { tinggi }\end{array}$ \\
\hline 8 & 0.6 & Cukup & 0.97 & $\begin{array}{l}\text { Sangat } \\
\text { tinggi }\end{array}$ \\
\hline 9 & 0.56 & Cukup & 0.97 & $\begin{array}{l}\text { Sangat } \\
\text { tinggi }\end{array}$ \\
\hline 10 & 0.5 & Cukup & 0.94 & $\begin{array}{c}\text { Sangat } \\
\text { tinggi }\end{array}$ \\
\hline 11 & 0.53 & Cukup & 0.97 & $\begin{array}{c}\text { Sangat } \\
\text { tinggi }\end{array}$ \\
\hline 12 & 0.67 & Tinggi & 0.94 & $\begin{array}{c}\text { Sangat } \\
\text { tinggi }\end{array}$ \\
\hline 13 & 0.8 & Tinggi & 0.97 & $\begin{array}{l}\text { Sangat } \\
\text { tinggi }\end{array}$ \\
\hline 14 & 0.67 & Tinggi & 1 & $\begin{array}{l}\text { Sangat } \\
\text { tinggi }\end{array}$ \\
\hline 15 & 0.49 & Cukup & 0.87 & $\begin{array}{c}\text { Sangat } \\
\text { tinggi }\end{array}$ \\
\hline $\begin{array}{c}\text { Rata- } \\
\text { rata }\end{array}$ & 0,60 & Cukup & 0,94 & $\begin{array}{c}\text { Sangat } \\
\text { tinggi }\end{array}$ \\
\hline
\end{tabular}


Hasil validasi tahap pertama produk instrumen penalaran ilmiah pada materi sistem pertahanan tubuh diketahui masih perlu adanya revisi dilihat dari saran-saran validator terkait kejelasan bahasa, kesesuaian indikator penalaran ilmiah dengan soal, dan kesesuaian konsep pada indikator pembelajaran dengan indikator penalaran ilmiah. Adapun saran untuk perbaikan produk dapat dilihat pada Gambar 1 sampai Gambar.

Ala beberapa lealimat yang tata letalenya hans ofiperbahani

Gambar 1. Saran tentang Aspek Kejelasan Kebahasaan

Ada beberapa soal jang diperbatic lag, redalss perryatacan balain Soal mavpun redalssi pertangan diperbarui Kembali

Gambar 2. Saran tentang Aspek Kesesuaian Indikator Penalaran Ilmiah dalam soal

Beberapa soal yg memiliki weservalan antara indikator pembelajaran dengan indikator penaleran llmiah yy leurang baik y disesucakan

Gambar 3. Saran tentang Aspek Kesesuaian Konsep pada Indikator Pembelajaran dengan Indikator Penalaran Ilmiah

\section{Pembahasan \\ Tahap Define}

Berdasarkan hasil wawancara, diperoleh informasi bahwa pembelajaran di sekolah menekankan penilaian pada Kurikulum 2013 yang menuntun siswa untuk dapat memecahkan masalah. Proses pembelajaran menggunakan metode-metode pembelajaran yang memberikan pemahaman kepada siswa terkait konsep-konsep yang diajarkan. Penilaian siswa dilakukan melalui ulangan harian, ujian tengah semester dan ujian akhir untuk mengukur tingkat keberhasilan siswa mencapai Kompetensi Dasar. Penilaian pembelajaran menggunakan tes sebagai alat untuk mengukur kemampuan siswa. Penilaian tes sudah berorientasi pada soal-soal pemecahan masalah. Namun, belum menyentuh pada kemampuan bernalar ilmiah, sehingga guru belum memiliki instrumen tes penalaran ilmiah. Penalaran ilmiah merupakan keterampilan tingkat tinggi atau higher order thinking yang harus dimiliki oleh siswa SMA/MA sederajat di abad 21 yang memberikan kontribusi dalam keterampilan kognitif siswa (Nur'Aini et al., 2018), penalaran ilmiah sebagai faktor dalam mendorong kinerja siswa dalam pembelajaran Sains untuk meningkatkan sumber daya manusia di abad ke-21 (Erlina et al., 2016) dan tujuan pengembangan kurikulum 2013 yang mengungkapkan pentingnya kemampuan bernalar untuk ditanamkan sejak dini pada tingkat satuan pendidikan (Permendikbud, 2013).

\section{Tahap Design}

Perancangan produk didesain berdasarkan analisis silabus untuk menentukan materi, sehingga dipilih sistem pertahanan tubuh. Pemilihan materi sejalan dengan pendapat Pribadi et al., (2018) yang menyebutkan bahwa materi sistem pertahanan tubuh merupakan materi dengan konsep yang kompleks karena dalam memahami proses pada sistem organnya tidak dapat diamati secara langsung, sehingga salah memahami konsep akan berpeluang mengakibatkan miskonsepsi. Perancangan produk berupa instrumen tes penalaran ilmiah mengacu pada Lawson (2004).

Indikator penalaran ilmiah pertama yaitu penalaran konservasi. Indikator tersebut menuntut siswa untuk dapat memahami bahwa sifat-sifat tertentu pada benda tidak berubah (Sari et al., 2019). Hal ini sesuai dengan indikator pembelajaran yaitu mengetahui fungsi dan pentingnya sistem pertahanan tubuh, dan menemukan penyebab terjadinya suatu penyakit. Penerapan kedua indikator tertuang dalam soal nomor 1 dan 11 .

Indikator penalaran ilmiah kedua yaitu penalaran proposional. Indicator tersebut menuntut siswa untuk menafsirkan hubungan dalam situasi yang digambarkan oleh variabel yang diamati (Irawati, 2016). Hal ini sesuai dengan indikator pembelajaran yaitu meyelidiki reaksi sistem pertahanan tubuh dalam melawan bakteri atau virus. Penerapan kedua indikator tertuang dalam soal nomor 2 .

Indikator penalaran ilmiah ketiga yaitu pengontrol variabel. Indikator tersebut menuntut siswa untuk dapat terfokus pada obyek yang sedang diamati (Shofiyah \& Wulandari, 2018). $\mathrm{Hal}$ ini sesuai dengan indikator pembelajaran yaitu menjelaskan fungsi dan pentingnya sistem 
pertahanan tubuh, menemukan penyebab terjadinya suatu penyakit, dan mengemukakan peran pertahanan nonspesifik atau spesifik. Penerapan kedua indikator tertuang dalam soal nomor 3, 4 dan 12.

Indikator penalaran ilmiah keempat yaitu penalaran probabilistik. Indikator tersebut menuntut siswa untuk dapat menggunakan informasi untuk memutuskan suatu kesimpulan (Sari, 2015). Hal ini sesuai dengan indikator pembelajaran yaitu memaparkan interaksi antibodi dan antigen, dan menyelidiki reaksi sistem pertahanan tubuh dalam melawan bakteri atau virus. Penerapan kedua indikator tertuang dalam soal nomor 5, 6 dan 13.

Indikator penalaran ilmiah kelima yaitu penalaran korelasi. Indikator tersebut menuntut siswa untuk dapat mengidentifikasikan dan menentukan hubungan timbal balik antar variabel (Rimadani et al., 2017). Hal ini sesuai dengan indikator pembelajaran yaitu menemukan penyebab terjadinya suatu penyakit, dan meyelidiki reaksi sistem pertahanan tubuh dalam melawan bakteri atau virus. Penerapan kedua indikator tertuang dalam soal nomor 7, 8 dan 14 .

Indikator penalaran ilmiah keenam yaitu penalaran hipotesis deduktif. Indikator tersebut menuntut siswa untuk dapat membentuk hipotesis dari teori-teori umum yang diikuti oleh deduksi untuk mengembangkan solusi terhadap masalah akan terjadi dalam eksperimen (Andani et al., 2018). Hal ini sesuai dengan indikator pembelajaran yaitu mengemukakan peran pertahanan nonspesifik atau spesifik, menjelaskan fungsi dan pentingnya sistem pertahanan tubuh, dan membandingkan mekanisme kerja pertahanan nonspesifik dan spesifik. Penerapan kedua indikator tertuang dalam soal nomor 9, 10 dan 15 .

\section{Tahap Develop}

Tahap Develop dilakukan dengan dua kali validasi produk. Hal ini disebabkan pada validasi pertama masih banyak soal yang masuk ke dalam kriteria cukup valid. Selain itu, masih banyak catatan saran dari validator untuk perbaikan produk. Catatan validator meliputi aspek kejelasan bahasa, kesesuaian indikator penalaran ilmiah dengan butir soal dan kesesuaian konsep indikator pembelajaran dengan indikator penalaran ilmiah. Soal-soal yang sudah divalidasi tahap pertama kemudian direvisi dan divalidasi kembali.

Hasil validasi pertama indikator penalaran konservasi (nomor 1 dan 11) berada pada kategori cukup valid yang dilihat pada Tabel 2 . Soal-soal pada indikator tersebut mendapatkan saran ketidaksesuaian dalam aspek kejelasan bahasa, kesesuaian indikator penalaran ilmiah dengan soal, dan kesesuaian konsep indikator pembelajaran dengan indikator penalaran ilmiah belum tepat dalam informasi yang disuguhkan. Saran validator sejalan dengan pendapat Kartowagiran, (2012) yang menyebutkan pembuatan butir soal harus memperhatikan aspek yang dinilai dalam soal untuk mencapai tujuan dari pembelajaran. Pembuatan soal penalaran konservasi harus menilai kemampuan siswa dalam mempertahankan konsep sifat pada objek yang diamati tidak akan berubah, meski terdapat objek lain yang mempengaruhi (Wardani, 2018). Hasil revisi soal kemudian divalidasi tahap kedua dan memperoleh hasil baik dengan kategori validitas sangat tinggi dilihat dari peningkatan nilai yang terdapat pada Tabel 2.

Hasil validasi pertama indikator penalaran proposional (nomor 2) berada pada kategori kategori validitas tinggi yang dilihat pada Tabel 2. Soal-soal pada indikator tersebut mendapatkan saran ketidaksesuaian dalam aspek kejelasan bahasa dalam soal sudah tepat dalam menilai aspek indikator penalaran imiah dan indikator pembelajaran, akan tetapi keterbacaan redaksi pertanyaan perlu diperbaiki karena memiliki dua variabel yang belum terfokus pada obyek yang diamati. Saran tersebut sejalan dengan pendapat Muzaffar, (2016) yang menyebutkan bahwa kriteria butir soal yang berkualitas baik harus memiliki format tes sesuai dengan tujuan tes yang dinilai. Pembuatan soal penalaran proposional harus menilai suatu kemampuan berfikir siswa yang didasari pada konsep dalam memahami hubungan antara objek yang diamati dengan objek lainnya (Irawati, 2016). Hasil revisi soal kemudian divalidasi tahap kedua dan memperoleh hasil baik dengan kategori validitas sangat tinggi dilihat dari peningkatan nilai yang terdapat pada Tabel 2 .

Hasil validasi pertama indikator pengontrol variabel (nomor 3, 4 dan 12) berada pada kategori validitas tinggi yang dilihat pada Tabel 2. Soal-soal indikator tersebut mendapatkan 
saran ketidaksesuaian dalam aspek ketatabahasaan dalam pertanyaan mengandung kalimat tidak efektif yang menyebabkan soal belum mengukur penalaran pengontrol variabel dan indikator pembelajaran. Saran validator sejalan dengan pendapat dengan Arifin (2016) yang menyebutkan bahwa penggunaan kalimat yang tidak efektif akan membuat siswa sulit untuk memahami soal. Pembuatan soal pengontrol variabel harus menilai kemampuan dalam mengenali keperluan-keperluan yang dibutuhkan dalam suatu eksperimen dan variabel-variabel yang akan diinvestigasi (Shofiyah \& Wulandari, 2018). Hasil revisi soal kemudian divalidasi tahap kedua dan memperoleh hasil baik dengan kategori validitas sangat tinggi dilihat dari peningkatan nilai yang terdapat pada Tabel 2 .

Hasil validasi pertama indikator penalaran probabilistik (nomor 5, 6 dan 13) berada pada kategori validitas tinggi yang dilihat pada Tabel 2. Soal-soal pada indikator tersebut mendapatkan saran ketidaksesuaian dalam aspek kejelasan bahasa antara pernyataan informasi yang disuguhkan dengan pertanyaan soal belum tepat dalam menilai aspek penalaran probabilistik dan indikator pembelajaran pada soal. Saran validator sejalan dengan pendapat Kusmiyati \& Prabawa, (2016) yang menyebutkan bahwa kalimat yang efektif digunakan untuk memahami pesan, gagasan, pikiran, maupun pemberitahuan sesuai dengan maksud yang diinginkan untuk dipahami oleh pembaca. Pembuatan soal penalaran probabilistik harus menilai kemampuan menghubungan objek diamati dari informasi yang disuguhkan (Sari et al., 2019). Hasil revisi soal kemudian divalidasi tahap kedua dan memperoleh hasil baik dengan kategori validitas sangat tinggi dilihat dari peningkatan nilai yang terdapat pada Tabel 2 .

Hasil validasi pertama indikator penalaran korelasi (nomor 7, 8 dan 14) berada pada kategori validitas cukup yang dilihat pada Tabel 2. Soal-soal pada indikator tersebut mendapatkan saran ketidaksesuaian dalam aspek kurangnya stimulus informasi untuk memahami pertanyaan hubungan timbal balik antar variabel dalam soal, sehingga penalaran korelasi dan indikator pembelajaran belum ternilai dalam soal. Saran validator sejalan dengan pendapat Fanani, (2018) yang menyatakan bahwa penyusunan soal HOTS umumnya menggunakan stimulus untuk membuat pertanyaan yang bersifat kontekstual dan menarik, stimulus dalam soal dapat bersumber dari isu-isu global. Pembuatan soal penalaran korelasi harus menilai kemampuan melibatkan identifikasi dan verifikasi hubungan antar variabel yang diamati dalam soal (Irawati, 2016). Hasil revisi soal kemudian divalidasi tahap kedua dan memperoleh hasil baik dengan kategori validitas sangat tinggi dilihat dari peningkatan nilai yang terdapat pada Tabel 2 .

Hasil validasi pertama indikator penalaran hipotesis deduktif (nomor 9, 10 dan 15) berada pada kategori validitas cukup yang dilihat pada Tabel 2. Soal-soal pada indicator tersebut mendapatkan saran ketidaksesuaian dalam aspek kejelasan bahasa pembuatan soal dengan teori-teori yang disuguhkan untuk mengembangkan solusi dalam menilai kemampuan hipotesis siswa belum muncul, sehingga aspek indikator penalaran hipotesis deduktif dan indikator pembelajaran belum ternilai dalam soal. Saran validator sejalan dengan pendapat Syamsurizal, (2020) yang menyebutkan bahwa validitas alat ukur dilihat dari derajat kesesuaian alat ukur dalam mengukur suatu aspek yang diinginkan. Pembuatan soal hipotesis deduktif harus menilai kemampuan identifikasi siswa dalam menganalisis objek yang diamati dari teori-teori (Han, 2013). Hasil revisi soal kemudian divalidasi tahap kedua dan memperoleh hasil baik dengan kategori validitas sangat tinggi dilihat dari peningkatan nilai yang terdapat pada Tabel 2.

\section{SIMPULAN}

Hasil validasi yang dilakukan dua kali berada pada kategori validitas sangat tinggi yang menunjukan bahwa produk instrumen penalaran ilmiah pada materi sistem pertahanan tubuh kelas XI yang peneliti kembangkan layak untuk digunakan.

\section{REFERENSI}

Andani, I. D., Prastowo, S. H. B., \& Supeno. (2018). Identifikasi Kemampuan Penalaran Hipotesis-deduktif Siswa SMA dalam Pembelajaran Fisika Materi Hukum Newton. Seminar Nasional Quantum, 25, 562-568.

Arifin, R. (2016). Keefektifan Kalimat pada Naskah Soal Ujian Akhir Semester Ganjil 
Quagga: Jurnal Pendidikan dan Biologi

Volume 13, Nomor 1, Januari 2021, pp.26-33
p-ISSN 1907-3089, e-ISSN2651-5869

https://journal.uniku.ac.id/index.php/quagga
Kelas VIII SMPN di Metro Tahun Pelajaran 2015/2016. Universitas Lampung.

Aripin, I. (2018). Pengembangan Soal-soal Pilihan Ganda untuk Mengukur Kemampuan Berpikir Kritis Siswa pada Konsep Sistem Regulasi Manusia untuk Jenjang SMA. Jurnal Mangifera Edu, 3(1), 26-39.

Coletta, V. P., Phillips, J. A., Savinainen, A., \& Steinert, J. J. (2008). Comment on "The Effects of Students" Reasoning Abilities on Conceptual Understanding and Problem-solving Skills in Introductory Mechanics'. European Journal of Physics, 29(5), 1-5. https://doi.org/10.1088/01430807/29/5/L01

Erlina, N., Supeno, \& Wicaksono, I. (2016). Penalaran Ilmiah Dalam Pembelajaran Fisika. Prosiding Seminar Nasional Tahun 2016 " Mengubah Karya Akademik Menjadi Karya Bernilai Ekonomi Tinggi ," 473-480.

Fadillah, E. N. (2017). Pengembangan Instrumen Penilaian Untuk Mengukur Keterampilan Proses Sains Siswa Sma. Jurnal Penelitian Pendidikan Biologi, 1(2), 123-134.

Fanani, M. Z. (2018). Strategi Pengembangan Soal Higher Order Thinking Skill (HOTS) dalam Kurikulum 2013. Journal of Islamic Religious Education, 2(1), 5776.

Han, J. (2013). Scientific Reasoning: Research, Development, and Assessment. The Ohio State University.

Irawati, T. N. (2016). Pengembangan Paket Tes Kemampuan Penalaran Proposional Siswa SMP. Universitas Jember.

Kartowagiran, B. (2012). Penulisan Butir Soal. Universitas Negeri Yogyakarta.

Khoirina, M., Cari, C., \& Sukarmin. (2018). Identify Students' Scientific Reasoning Ability at Senior High School. Journal of Physics: Conference Series, 1097(1). https://doi.org/10.1088/17426596/1097/1/012024

Kusmiyati, I., \& Prabawa, A. H. (2016). Penggunaan Kalimat Efektif pada Soal Latihan dalam Buku Paket Bahasa Indonesia SMP Kelas VII Karya Mariati Nugroho dan Sutopo. Universitas
Muhammadiyah Surakarta.

Lamapaha, Y. F. (2017). Pengembangan Lembar Kerja Siswa Berbasis Kontekstual Berorientasi Penalaran Saintifik. Jurnal Pendidikan Matematika Dan Sains, 5(1), 58-68. https://doi.org/10.21831/jpms.v5i1.1354 1

Lawson, A. E. (2004). The nature and development of scientific reasoning: A synthetic view. International Journal of Science and Mathematics Education, 2(3), 307-338. https://doi.org/10.1007/s10763-0043224-2

Muzaffar, A. (2016). Validitas Tes dan Kualitas Butir Soal. Lisanuna: Jurnal Bahasa Arab Dan Pembelajarannya, 5, 128-143.

Novia, \& Riandi. (2017). The Analysis of Students Scientific Reasoning Ability in Solving the Modified Lawson Classroom Test Of Scientific Reasoning (MLCTSR) Problems by Applying The Levels of Inquiry. Jurnal Pendidikan IPA Indonesia, $\quad 6(1), \quad 116-122$. https://doi.org/10.15294/jpii.v6i1.9600

Nur'Aini, Subiki, \& Supriadi, B. (2018). Identifikasi Kemampuan Penalaran Ilmiah (Scientific Reasoning) Siswa SMA di Kabupaten Jember pada Pokok Bahasan Dinamika. Seminar Nasional Pendidikan Fisika 2018, 3, 121-126.

Permendikbud. (2013). Kerangka Dasar dan Struktur Kurikulum Sekolah Menengah Atas/Madrasah Aliyah. Jakarta: Kementerian Pendidikan dan Kebudayaan Republik Indonesia.

Pribadi, A. P., Yuliati, \& Nurcahyo, H. (2018). Analisis Miskonsepsi pada Konsep Sistem Kekebalan Tubuh dalam Buku Ajar Biologi SMA di Yogyakarta. Jurnal Prodi Pendidikan Biologi, 7(2), 160-167.

Purwati, S., Handayanto, S. K., \& Zulaikah, S. (2016). Korelasi Antara Penalaran Ilmiah dan Pemahaman Konsep Siswa pada Materi Usaha dan Energi. Seminar Nasional Pendidikan IPA Pascasarjana $U M, 1$.

Rasyid, A., Gaffar, A. A., \& Utari, W. (2020). Efektivitas Aplikasi Mobile Learning Role Play Games (RPG) Maker MV untuk Meningkatkan Kemampuan Berpikir Kritis. Jurnal Mangifera Edu, 
4(2), 107-115.

Rimadani, E., Parno, \& Diantoro, M. (2017). Identifikasi Kemampuan Penalaran Ilmiah Siswa Sma Pada Materi Suhu Dan Kalor. Jurnal Pendidikan: Teori, Penelitian Dan Pengembangan, 2(6), 833-839.

Rochmad. (2012). Desain Model Pengembangan Perangkat Pembelajaran Matematika. Jurnal Kreano, 3(1), 59-72.

Saad, M. I. M., Baharom, S., \& Mokhsein, S. E. (2017). Scientific Reasoning Skills Based on Socio-scientific Issues in the Biology Subject. International Journal of Advanced and Applied Sciences, 4(3), 1318.

Saptaningrum, E., Nuvitalia, D., \& Patonah, S. (2019). Kemampuan Mahasiswa Pendidikan Fisika Universitas PGRI Semarang dalam Menggunakan Kata Kerja Operasinal Ranah Kognitif pada Penyusunan Tes Tertulis. Prosiding Seminar Nasional.

Sari, D. I. (2015). Profil Berpikir Probabilistik Siswa Sekolah Dasar (SD) Berkemampuan Matematika Tinggi Dalam Menyelesaikan Tugas Probabilitas. Seminar Nasional Matematika Dan Pendidikan Matematika UNY, 2, 1123-1130.

Sari, L. I., Zulhelmi, \& Azizahwati. (2019). An Analysis Scientific Reasoning Ability of Class X Student Sma Negeri at Tampan District Pekanbaru in Subject Work and Energy. JOM FKIP, 6(2), 1-14.

Shofiyah, N., \& Wulandari, F. E. (2018). Model Problem Based Learning (PBL) dalam Melatih Scientific Reasoning Siswa. Jurnal Penelitian Pendidikan IPA, 3(1), 33-38.

Syamsurizal. (2020). Validitas dan Reliabitas Alat Ukur. Jurnal Osf, 1-11.

Utama, Z. P., Maison, \& Syarkowi, A. (2018). Analisis Kemampuan Bernalar Siswa SMA Kota Jambi. Jurnal Penelitian Pembelajaran Fisika, 9(1), 1-5. https://doi.org/10.26877/jp2f.v9i1.2223

Wardani, P. O. (2018). Identifikasi Kemampuan Penalaran Ilmiah Siswa SMKN 2 Jember tentang Rangkaian Listrik menggunakan Baterai Ganda pada Pembelajaran Fisika. Universitas Jember.
Zimmerman, C. (2005). The Development of Scientific Reasoning Skills: What Psychologists Contribute to an Understanding of Elementary Science Learning. National Research Concil, 1109. 